\title{
The Correlation of Ergonomic Risk Factor with Musculoskeletal Complaints in Batik Workers
}

\author{
Hubungan Faktor Risiko Ergonomi dengan Keluhan Muskuloskeletal pada \\ Pembatik
}

\author{
Galuh Sistha Prabarukmi, Noeroel Widajati \\ Department of Occupational Safety and Health, Faculty of Public Health, Universitas Airlangga \\ Campus C Mulyorejo, Surabaya, East Java, 60115 Indonesia
}

\begin{abstract}
Introduction: Batik is one of Indonesia's cultural wealth which was established as an intangible cultural heritage by UNESCO in 2009. Batik fabrics have been actively produced in both micro and macro industries in Indonesia. The process of batik production still faithfully employs manual labor. The large number of workers involved in batik production activities causes them to potentially suffer from occupational diseases such as musculoskeletal disorders. Various factors can cause workers to suffer from musculoskeletal complaints, one of them is ergonomic factor. Batik Madura home industry is one of the largest batik-producing home industries in Bangkalan District, Madura. This study object was to determine the correlation between ergonomic risk factors and musculoskeletal complaints in workers of Batik Madura home industry. Methods: This was an observational study through cross sectional design. Data collection was conducted through observation and interviews with the workers of Batik Madura home industry. The population in this study was 61 workers of Batik Madura home industry. This study used total sampling technique in which the whole population were taken as the sample. Results: There was a very strong correlation of ergonomic chance factor with musculoskeletal complaints $(\mathrm{r}=0.876)$ on workers of Batik Madura home industry. Conclusion: There was a very strong correlation of ergonomic chance factor with musculoskeletal complaints $(r=0.876)$ on workers of Batik Madura home industry.
\end{abstract}

Keywords: ergonomic risk factor, musculoskeletal complaints, batik workers

\section{ABSTRAK}

Pendahuluan: Batik adalah kekayaan budaya milik bangsa Indonesia yang pada tahun 2009 ditetapkan oleh UNESCO sebagai Warisan Budaya Tak Benda. Kain batik telah diproduksi oleh berbagai industri di Indonesia, baik industri mikro maupun industri makro. Pembuatan kain batik di Indonesia masih menggunakan tenaga manusia dalam kegiatan produksinya. Banyaknya pekerja yang terlibat dalam aktivitas kegiatan produksi industri batik menyebabkan pekerja berpotensi mengalami penyakit akibat kerja seperti keluhan Muskuloskeletal. Berbagai faktor yang dapat menyebabkan pekerja mengalami keluhan Muskuloskeletal, salah satunya yakni faktor risiko ergonomi. Home industry batik Madura menjadi salah satu home industry penghasil batik terbesar di Kabupaten Bangkalan, Madura. Penelitian ini bertujuan untuk mengetahui hubungan faktor risiko ergonomi dengan keluhan Muskuloskeletal pada pembatik di home industry batik Madura. Metode: Penelitian ini merupakan penelitian observasional. Rancang bangun yang digunakan dalam penelitian ini adalah cross-sectional study. Pengumpulan data dilakukan dengan cara observasi dan wawancara dengan pembatik di home industry batik Madura. Populasi yang digunakan dalam penelitian ini yakni 61 pembatik di home industry batik Madura dengan teknik pengambilan sampel berupa total sampling sehingga seluruh populasi dijadikan sampel penelitian. Hasil: Terdapat hubungan yang sangat kuat antara faktor risiko ergonomi dengan keluhan Muskuloskeletal ( $r=0.876)$ pada pembatik home industry batik Madura. Simpulan: Faktor yang sangat signifikan menyebabkan keluhan Muskuloskeletal pada pembatik di home industry batik Madura adalah faktor risiko ergonomi.

Kata kunci: faktor risiko ergonomi, keluhan muskuloskeletal, pembatik

Corresponding Author:

Galuh Sistha Prabarukmi

Email: galuhsisthaaa@gmail.com

Telephone: +6282187877706

\section{INTRODUCTION}

Musculoskeletal Disorders can happen at any age. That is why Musculoskeletal Disorders is the primary contributor to universal malformation (World Health Organization, 2019). The Global 
Burden of Disease data for non-communicable diseases in 2016 showed that musculoskeletal disorders were identified as profound burden of disease perceived by community in the world (Briggs et al., 2018).

The data of Health Research and Development Agency (2013) showed prevalence of musculoskeletal complaints in Indonesia was $24.7 \%$. The study of health problem profile in Indonesia showed prevalence of workers in Indonesia suffering from musculoskeletal complaints was $16 \%$ (Sekaaram and Ani, 2017).

Industrial advancement in Indonesia is not counterbalanced with the stride in the utilization of technology in many industries. There are many industries in Indonesia that still rely heavily on manual labor in their production activities, which is not necessarily a bad thing. However, it comes with its own risk, which is musculoskeletal complaint in workers. One industry with high probability of musculoskeletal complaints is the micro industry such home industries. The Data of Statistics Indonesia from 2016 showed that the number of micro industry workers in Indonesia increased for 3 consecutive years, totaling 5,408,857 workers in 2013, 6,039,855 in 2014 and 6,464,396 in 2015 (Central Bureau of Statistics, 2016). The Data of Statistical Central Board of Indonesia in 2017 showed that the number of informal industry workers in Indonesia was 72.67 million workers (58.35\%) (Mulyati, 2019). The large number of workers in informal industries causes the workers to experience work accidents and illness due to increased work.

Pursuant to International Labor Organization in 2018 , there were 2.78 workers died every year because of work accidents and illness (International Labour Organization, 2018). One of the work related diseases that happens is Musculoskeletal Disorders.

Musculoskeletal Disorders are complaints felt by a person on the part of the skeletal muscles from not severe complaints to severe complaints (Tarwaka, 2019). Musculoskeletal Disorders are injury and pain felt by workers in the musculoskeletal system, including the nervous tract, tendons, muscles, and proponent fabrics of body parts as well as shoulders and back (Arifin, Kuswardinah and Deliana, 2020). Based on this definition, it can be concluded that Musculoskeletal Disorders are injuries and complaints of pain felt by someone on the musculoskeletal system due to work activities carried out. The musculoskeletal tract includes the nervous system, joints, ligaments, sinews, and brawns.

Musculoskeletal Disorders can be experienced by batik workers in Indonesia. The study conducted by Sumardiyono and Ada in 2014 showed that 33 of 50 batik workers in Sragen City suffered from Musculoskeletal Disorders (Sumardiyono and Ada, 2014). A study conducted by Dhari, Muliarta and Adiputra in batik artisans in batik industry showed that more than $60 \%$ batik workers have Musculoskeletal Disorders. According to study conducted by Oesman, Yusuf and Irawan (2012), it showed that $22 \%$ experienced musculoskeletal complaints. According to Marfuah (2018), Musculoskeletal Disorders experienced by $22 \%$ of batik workers in Batik Tulis Giriloyo, Yogyakarta. The study carried out by Harwanti, Ulfah and Aji (2017) showed that 37 batik workers in Sokaraja District endured Musculoskeletal Disorders complaints. According to Saputro, Mulyono and Puspikawati (2018), Musculoskeletal Disorders were suffered by batik artisans in Virdes Batik Collection Banyuwangi by $69.5 \%$. The study performed by Isnaini, Bagyono and Hendrarini (2019) showed that 26 of 48 batik workers suffered from Musculoskeletal Disorders.

Studies on musculoskeletal problems in batik artisans are plentiful. The study carried out by Ramadhiani, Widjasena and Jayanti (2017) showed that awkward posture while doing batik making in Kampoeng Batik Laweyan of Surakarta may cause ache in pivots, ligaments, and tendons, such shoulder pain. This condition is caused when the batik making process uses traditional work equipment. The study performed by Rosifah, Susmartini and Iftadi (2017) showed that unnatural posture during batik cap production in Batik Putri Mulyo led to musculoskeletal complaints among the batik workers.

The study conducted by Sumardiyono and Wijayanti (2018) showed that ergonomic risk factors greatly contributed to musculoskeletal complaints in batik workers. It is somewhat expected considering that during the production, they sit on an unergonomic working chair for an extended period of time. The study carried out by Lindawati and Mulyono (2018) in the batik craftsmen of Aleyya Batik Yogyakarta showed that Musculoskeletal Disorders experienced by batik craftsmen caused by unnatural posture. The study conducted by Saputro, Mulyono and Puspikawati (2018) showed that unergonomic working attitude 
during batik making process caused the greatest risk of musculoskeletal complaints in the batik craftsmen. The study carried out by Sari and Rifai (2019) also showed that unergonomic working postures led to musculoskeletal problems. The study conducted by Arifin (2020) showed that unnatural work positions of batik artisans are the greatest cause of musculoskeletal complaints suffered by batik workers in Suka Maju Giri Loyo Yogyakarta.

Batik Madura home industry is one of informal industries which grow rapidly in Bangkalan District. In the region, Tanjung Bumi Sub-District is among the largest producer and supplier of batik. The production activities in Batik Madura home industry consists of several steps, namely the washing of plain mori fabric (Ketel), the drawing of the outlines of batik pattern (Rengreng), the drawing of small patterns (Kuri), the application of wax using canting (Essean), the covering of fabric portion in which no patterns are drawn (Nebbeng), the process of dyeing which is performed twice, and removal or dissolution of wax using boiling water (Lorot). Based on the preliminary study, the equipment used in the production is operated manually and traditionally. The work stations used do not conform to anthropometric conditions of the workers. Field observation shows that every worker activity has the potential of causing musculoskeletal complaints. During the production, batik workers work in a sitting position on a mat laid on the floor and a small chair. When drawing the patterns, batik workers slightly bend their body toward different positions for an extended period of time, normally 3 to 6 hours of work with repetitive body movements. Unfortunately, this condition does not receive particular attention from the owners of home industry so musculoskeletal complaints experienced by batik artisans become worse.

Musculoskeletal Disorders are still experienced by many workers in informal industries such home industries. The incidence of Musculoskeletal Disorders in Indonesia will increase if it does not get special attention from the company management and home industry's owners. Musculoskeletal complaints that do not get handled properly can have an impact on work productivity and will be detrimental to the business owner. This research aimed to determine the correlation of ergonomic risk factors with musculoskeletal complaints in batik workers of Batik Madura home industry.

\section{METHODS}

This study was an observational study through cross-sectional design. The data collection was done through observation and interviews. The population in this study was all workers of Batik Madura home industry totaling 61 individuals. Sample calculation was performed using total sampling technique; thus, the entire population was involved as the study sample. The study was conducted from January 2020 at a home industry of Batik Madura's located at Jalan Pelabuhan II, Paseseh Village, Tanjung Bumi Sub-District, Bangkalan District. Variables used in this study composed by dependent and independent variables. The independent variable was ergonomic risk factor, while the dependent variable was musculoskeletal complaints. The measurement of ergonomic risk factors was carried out by observing the working position during batik making in home industry of Batik Madura. The results of the working position's observation then were analyzed using Rapid Entire Body Assessment (REBA). The assessment of musculoskeletal complaints was carried out by interviewing and filling the Nordic Body Map questionnaire which contained 28 body muscles experiencing complaints by the respondents with categories ranging from not painful to very painful. Data analysis was done by using Spearman correlation test with $\alpha$ of 0.05 .

This study was approved by Ethic Committee in Faculty of Dental Medicine of Universitas Airlangga. The registration of numeral of ethical clearance was 325/HRECC.FODM/VII/2020.

\section{RESULT}

\section{Individual Characteristics}

\section{Age}

The results of age were categorized into 5 categories, namely late teenager, preceded adult, late adult, preceded elder and late elder. Table 1 showed that 21 respondents (34.4\%) was in preceded adult, 15 respondents $(24.6 \%)$ was in late adult, 10 respondents $(19.7 \%)$ was in preceded elder, 10 respondents $(16.4 \%)$ was in late teenager and 3 respondents $(4.9 \%)$ was in late elder. 


\section{Exercise Habit}

The result of exercise habit were categorized into two categories, which are no and yes. Table 2 showed that 52 respondents $(85.2 \%)$ did not have exercise habit and 9 respondents $(14.8 \%)$ had exercise habit.

\section{Smoking Habit}

The result of smoking habit were categorized into 4 categories, those are never, $<7$ stick cigarettes per day, 1 pack cigarette and $\geq 2$ pack cigarettes per day. Table 3 showed that 56 respondents $(91.8 \%)$ had smoking habit in never category, 3 respondents (4.9\%) had smoking habit in $<7$ stick cigarettes per day category, 2 respondents $(3.3 \%)$ had smoking habit in 1 pack cigarette per day category and no one respondent had smoking habit in $\geq 2$ pack cigarettes per day category.

\section{Ergonomic Risk Factor}

The assessment of ergonomic risk factors on 61 workers of Batik Madura home industry was performed by documenting working positions of the workers during production activities in the form of photos or videos. The documentation results were then analyzed using the Rapid Entire Body Assessment (REBA) method. The REBA manner was divided into two groups, A and B. REBA Group $A$ analyzed body parts including neck, trunk and legs, while REBA Group B analyzed body parts including upper arms, forearms and wrists. The

Table 1. Distribution of Workers in Batik Madura's Home Industry's Age in January 2020

\begin{tabular}{ccc}
\hline Category & Frequency (n) & Percentage (\%) \\
\hline Late teenager & 10 & 16.4 \\
Preceded adult & 21 & 34.4 \\
Late adult & 15 & 24.6 \\
Preceded elder & 10 & 19.7 \\
Late elder & 3 & 4.9 \\
\hline Total & 61 & 100.0 \\
\hline
\end{tabular}

Table 2. The Distribution of Workers' Exercise Habit in Batik Madura home industry's in January 2020

\begin{tabular}{ccc}
\hline Category & Frequency $(\mathbf{n})$ & Percentage (\%) \\
\hline No & 52 & 85.2 \\
Yes & 9 & 14.8 \\
\hline Total & 61 & 100.0 \\
\hline
\end{tabular}

following figure is an example of ergonomic risk factor assessment using the REBA method.

Figure 1 showed that the worker's neck formed an angle of $0-20^{\circ}$, thus, a score of 1 was given for neck assessment. The worker's trunk formed an angle of $20-60^{\circ}$ forward, thus, a score of 3 was given for trunk assessment. The worker's legs were at a normal/balanced position forming a knee angle of $>$ $60^{\circ}$, thus a score of 3 was given for legs assessment. Batik activity carried a load of $<5 \mathrm{~kg}$, thus, load got a value of 0 . The scores for throat, trunk and legs positions were included in REBA Table A and the final value of REBA group A was 5. Batik workers work with the neck, trunk and legs position as shown in Figure 1 for 4 to 10 hours of office hours.

Figure 2 showed that the worker's upper arm formed an angle of $20-45^{\circ}$, thus, a score of 2 was given for upper arm assessment. The worker's forearm formed an angle of $<60^{\circ}$, thus, a score of 2 was given for forearm assessment. The wrist formed an angle of $>15^{\circ}$, thus, a score of 2 was given for wrist assessment. Coupling during the

Table 3. The Distribution of Workers' Smoking Habit in Batik Madura Home Industry's in January 2020

\begin{tabular}{ccc}
\hline Category & Frequency $(\mathbf{n})$ & Percentage (\%) \\
\hline $\begin{array}{c}\text { Never } \\
<7 \text { stick cigarettes } \\
\text { per day }\end{array}$ & 56 & 91.8 \\
$\begin{array}{c}\text { 1 pack cigarette per } \\
\text { day }\end{array}$ & 2 & 4.9 \\
$\geq 2$ pack cigarettes \\
per day
\end{tabular}

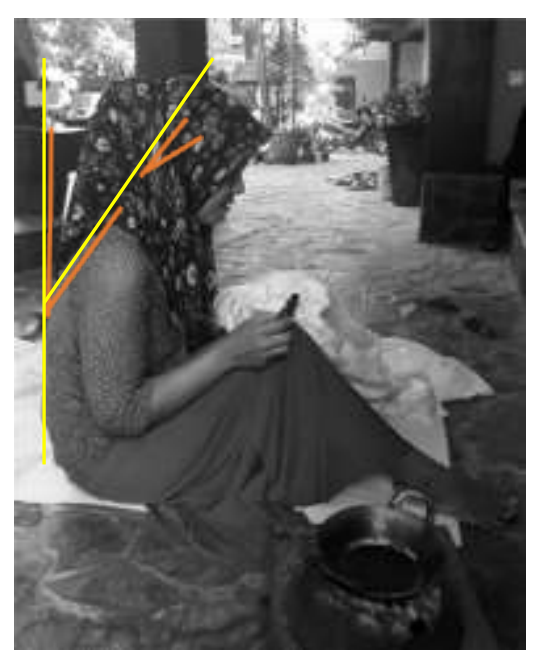

Figure 1. Group A REBA Assessment 
waxing activity was given a score of 0 because the grip on the canting was firm. The scores for upper arm, forearm and wrist positions were included in REBA Table B with a final score of 3 . The working position of the upper arm, forearm and wrist as shown in Figure 2 last for 4 to 10 hours during batik making process.

The calculation of group A and B's final scores was then presented in REBA Table $\mathrm{C}$ calculation and the final score for calculating ergonomic risk factors using the REBA method was 4. A score of 4 was considered in the moderate category of musculoskeletal complaints thus a control measure is needed. The calculation results of ergonomic risk factors on 61 batik artisans of Batik Madura home industry were shown in Table 4.

The results of ergonomic factor's assessment applied using the Rapid Entire Body Assessment (REBA) were categorized into 4 categories, which are low, medium, high and very high categories. Table 4 showed that 27 respondents $(44.3 \%)$ had ergonomic factor risk level in the high category, 20 respondents (32.8\%) were in very high category, 14 respondents $(23 \%)$ were in moderate category, and no respondent $(0 \%)$ were in low category.

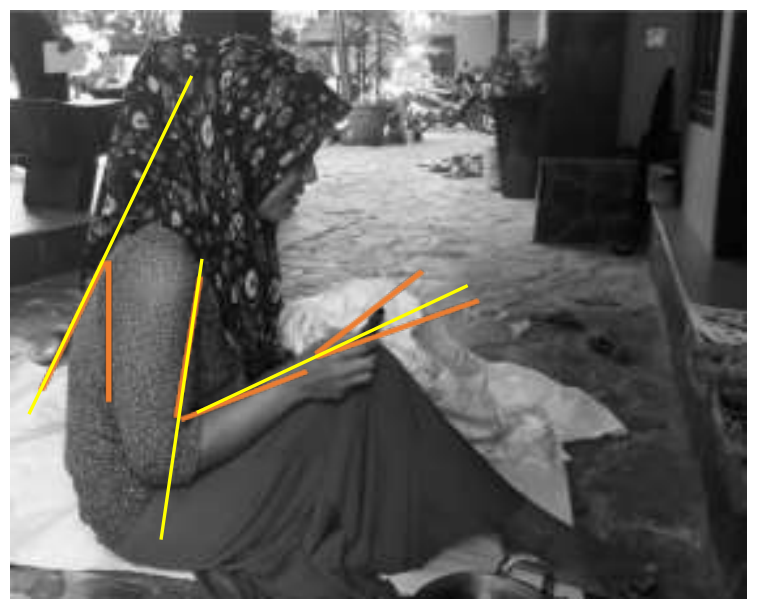

Figure 2. Group B REBA Assessment

Table 4. The distribution of Workers' Ergonomic Risk Factor in Batik Madura Home Industry's in January 2020

\begin{tabular}{ccc}
\hline Category & Frequency (n) & Percentage (\%) \\
\hline Low & 0 & 0.0 \\
Moderate & 14 & 23.0 \\
High & 27 & 44.2 \\
Very high & 20 & 32.8 \\
\hline Total & 61 & 100.0 \\
\hline
\end{tabular}

\section{Musculoskeletal Complaints}

Musculoskeletal complaint assessment on 61 workers of Batik Madura home industry was performed by interviews using Nordic Body Map questionnaire. The musculoskeletal complaints were categorized into low, medium, high and very high categories. Table 5 showed that the majority of musculoskeletal complaints from the workers were in the high category by 25 respondents (41\%). Furthermore, 20 respondents $(32.8 \%)$ reported complaints in the very high category and 16 respondents $(26.2 \%)$ reported in the medium category.

The assessment of musculoskeletal complaint using Nordic Body Map questionnaire was categorized into less painful, rather painful, painful and very painful. The result of musculoskeletal complaint on 61 workers in Batik Madura home industry using Nordic Body Map questionnaire showed that 28 respondents $(45.9 \%)$ felt very painful in the spine, 23 respondents $(37.7 \%)$ felt painful in the waist. The most rather pain felt by 23 respondents $(37.7 \%)$ was in the left leg and 21 respondents $(34.43 \%)$ felt less painful in the left elbow. The results of musculoskeletal complaint shown in Table 6.

Table 5. The Distribution of Workers' Musculoskeletal Complaints in Batik Madura Home Industry's in January 2020

\begin{tabular}{ccc}
\hline Category & Frequency (n) & Percentage (\%) \\
\hline Low & 0 & 0.0 \\
Medium & 16 & 26.2 \\
High & 25 & 41.0 \\
Very high & 20 & 32.8 \\
\hline Total & 61 & 100.0 \\
\hline
\end{tabular}

Table 7. The Distribution of Correlation between Ergonomic Factor and Musculoskeletal Complaints on Workers in Batik Madura Home Industry in January 2020

\begin{tabular}{|c|c|c|c|c|c|c|c|c|}
\hline \multirow{3}{*}{$\begin{array}{l}\text { Ergonomic } \\
\text { Factor }\end{array}$} & \multicolumn{6}{|c|}{ Musculoskeletal Complaints } & \multirow{2}{*}{\multicolumn{2}{|c|}{ Total }} \\
\hline & \multicolumn{2}{|c|}{ Medium } & \multicolumn{2}{|c|}{ High } & \multicolumn{2}{|c|}{$\underset{\text { High }}{V \text { e r }} \mathbf{y}$} & & \\
\hline & $\mathbf{n}$ & $\%$ & n & $\%$ & $\mathbf{n}$ & $\%$ & $\mathbf{N}$ & $\%$ \\
\hline Moderate & 11 & 78.6 & 3 & 21.4 & 0 & 0.0 & 14 & 100 \\
\hline High & 5 & 18.5 & 21 & 77.8 & 1 & 3.7 & 27 & 100 \\
\hline Very High & 0 & 0.0 & 1 & 5.0 & 19 & 95.0 & 20 & 100 \\
\hline Correlatic & $\mathrm{n} \mathrm{C}$ & efficis & & & & 0.876 & & \\
\hline
\end{tabular}


Table 6. The Distribution of Musculoskeletal Complaints Location on Workers in Batik Madura Home Industry in January 2020

\begin{tabular}{|c|c|c|c|c|c|c|c|c|c|c|}
\hline \multirow{2}{*}{ Organ } & \multicolumn{2}{|c|}{ Less Pain } & \multicolumn{2}{|c|}{ Rather Pain } & \multicolumn{2}{|c|}{ Pain } & \multicolumn{2}{|c|}{ Very Pain } & \multicolumn{2}{|c|}{ Total } \\
\hline & $\mathrm{n}$ & $\%$ & $\mathrm{n}$ & $\%$ & n & $\%$ & $\mathrm{n}$ & $\%$ & $\mathbf{N}$ & $\%$ \\
\hline Upper neck & 15 & 24.59 & 12 & 19.67 & 20 & 32.79 & 14 & 22.95 & 61 & 100.00 \\
\hline Lower neck & 11 & 18.03 & 12 & 19.67 & 16 & 26.23 & 22 & 36.07 & 61 & 100.00 \\
\hline Left shoulder & 12 & 19.67 & 16 & 26.23 & 16 & 26.23 & 17 & 27.87 & 61 & 100.00 \\
\hline Right shoulder & 11 & 18.03 & 16 & 26.23 & 16 & 26.23 & 18 & 29.51 & 61 & 100.00 \\
\hline Left upper arm & 12 & 19.67 & 12 & 19.67 & 17 & 27.87 & 20 & 32.79 & 61 & 100.00 \\
\hline Spine & 8 & 13.11 & 9 & 14.75 & 16 & 26.23 & 28 & 45.90 & 61 & 100.00 \\
\hline Right upper arm & 8 & 13.11 & 9 & 14.75 & 19 & 31.15 & 25 & 40.98 & 61 & 100.00 \\
\hline Waist & 7 & 11.48 & 8 & 13.11 & 23 & 37.70 & 23 & 37.70 & 61 & 100.00 \\
\hline Buttock & 9 & 14.75 & 7 & 11.48 & 20 & 32.79 & 25 & 40.98 & 61 & 100.00 \\
\hline Buttom & 8 & 13.11 & 10 & 16.39 & 17 & 27.87 & 26 & 42.62 & 61 & 100.00 \\
\hline Left elbow & 21 & 34.43 & 22 & 36.07 & 9 & 14.75 & 9 & 14.75 & 61 & 100.00 \\
\hline Right elbow & 17 & 27.87 & 13 & 21.31 & 17 & 27.87 & 14 & 22.95 & 61 & 100.00 \\
\hline Left lower arm & 9 & 14.75 & 17 & 27.87 & 17 & 27.87 & 18 & 29.51 & 61 & 100.00 \\
\hline Right lower arm & 9 & 14.75 & 17 & 27.87 & 19 & 31.15 & 16 & 26.23 & 61 & 100.00 \\
\hline Left wrist & 10 & 16.39 & 11 & 18.03 & 20 & 32.79 & 20 & 32.79 & 61 & 100.00 \\
\hline Right wrist & 10 & 16.39 & 12 & 19.67 & 18 & 29.51 & 21 & 34.43 & 61 & 100.00 \\
\hline Left hand & 20 & 32.79 & 17 & 27.87 & 13 & 21.31 & 11 & 18.03 & 61 & 100.00 \\
\hline Right hand & 18 & 29.51 & 20 & 32.79 & 8 & 13.11 & 15 & 24.59 & 61 & 100.00 \\
\hline Left thigh & 14 & 22.95 & 10 & 16.39 & 10 & 16.39 & 27 & 44.26 & 61 & 100.00 \\
\hline Right thigh & 15 & 24.59 & 12 & 19.67 & 10 & 16.39 & 24 & 39.34 & 61 & 100.00 \\
\hline Left knee & 13 & 21.31 & 13 & 21.31 & 18 & 29.51 & 17 & 27.87 & 61 & 100.00 \\
\hline Right knee & 16 & 26.23 & 11 & 18.03 & 14 & 22.95 & 20 & 32.79 & 61 & 100.00 \\
\hline Left calf & 9 & 14.75 & 14 & 22.95 & 20 & 32.79 & 18 & 29.51 & 61 & 100.00 \\
\hline Right calf & 10 & 16.39 & 12 & 19.67 & 17 & 27.87 & 22 & 36.07 & 61 & 100.00 \\
\hline Left ankle & 15 & 24.59 & 19 & 31.15 & 12 & 19.67 & 15 & 24.59 & 61 & 100.00 \\
\hline Right ankle & 15 & 24.59 & 14 & 22.95 & 15 & 24.59 & 17 & 27.87 & 61 & 100.00 \\
\hline Left leg & 17 & 27.87 & 23 & 37.70 & 14 & 22.95 & 7 & 11.48 & 61 & 100.00 \\
\hline Right leg & 19 & 31.15 & 11 & 18.03 & 20 & 32.79 & 11 & 18.03 & 61 & 100.00 \\
\hline
\end{tabular}

\section{The Correlation between Ergonomic Factor and Musculoskeletal Complaints}

Table 7, the statistical test using Spearman Correlation produced Correlation Coefficient value of 0.876 so that the correlation between ergonomic factor and musculoskeletal complaints was very strong with positive correlation direction.

\section{DISCUSSION}

\section{Individual Characteristics}

Age

The finding of this study regarding age showed that the majority of respondents are in preceded adult by $34.4 \%$. Age is one of the risk factors affecting musculoskeletal complaints. Someone who is in higher age group had a high prevalence of musculoskeletal complaints (Subramaniam and Murugesan, 2015). Another study showed that musculoskeletal complaints most often felt in the middle age then will increase as the age of workers increase. This condition was due to middle age when the strength and endurance of muscles possessed by someone begins to decrease (Hasanah and Winarko, 2019).

\section{Exercise Habit}

The result of this study regarding exercise habit showed that majority of respondents did not have exercise habit. This is because most of workers of 
Batik Madura home industry have side jobs. After working at Batik Madura home industry, they work as farm laborers, farmers, washing laborers, traders, and construction workers to fulfill their daily needs. If the workers have free time, it will be used for rest time.

Someone who has enough time to exercise will not easily experience musculoskeletal complaints (Cindyastira, Russeng and Wahyuni, 2014). According to Hardianto, Trisnawati and Rossa (2015) someone who has exercise habit less than once a week has the potential to suffer from Musculoskeletal Disorders complaints than people who routinely have exercise habit at least once a week. Exercise has an important role in strengthening musculoskeletal muscles, increasing aerobic capacity and general physical fitness.

\section{Smoking Habit}

The result of this study regarding smoking habit showed that millions of respondents do not have smoking habit. This condition is because Batik Madura home industry employed more female workers, where the majority of female population in Indonesia does not have a smoking habit.

Smoking habit is closely related to the condition of one's physical fitness. Smoking causes decrease in the lungs capacity. This condition causes a decrease in the ability of the lungs to consume oxygen so that the impact on the body's freshness level will also decrease. This condition also causes the carbohydrate combustion process to be obstructed and a buildup of lactic acid can occur and cause pain in the muscles (Saputro, Mulyono and Puspikawati, 2018). According to Hasanah and Winarko (2019) the dangers posed by cigarettes are chronic, so there is a possibility that the dangers arising from the smoking habit have not been seen to affect the musculoskeletal system in causing Musculoskeletal Disorders.

\section{The Correlation between Ergonomic Factor and Musculoskeletal Complaints}

The statistical analysis using the Spearman correlation produced a Correlation Coefficient value of 0.876 . The correlation between ergonomic factor and musculoskeletal complaints was strong with a direct relationship. This shows that the greater the ergonomic risk factors are, the more severe the musculoskeletal complaints will be. Body parts on which pain is felt most severe included the back, left thigh, right upper arm and buttocks. Meanwhile, body parts with the least pain were left elbow, left leg and left arm.

The strong relationship between ergonomic risk factors and musculoskeletal complaints is caused by odd work postures during batik making, static work positions for a longtime during batik making, repetitive movements on several limbs and work buildings which are not suitable with the anthropometric conditions of the workers.

Batik workers frequently experience static body postures in lower body organs, such as legs, thighs and knees. Batik workers also experience repetitive body posture in upper body organs, such as upper arms, shoulders and hands (Permatasari and Widajati, 2018).

The results appropriated with the theory by Gatchel (2014) stating that ergonomic risk factors are the chief factor causing musculoskeletal complaints in workers. Keyserling (2015) said that ergonomic risk factors are one of many biomechanical factors that give big contribution of musculoskeletal complaints in the workers. Ergonomic risk factors with repetitive movement caused repetitive strain injury that will have an impact on the emergence of musculoskeletal complaints (Graveling, 2019). It is also in line with the study performed by Evadarianto and Dwiyanti (2017) showing that there was a very strong correlation between ergonomic risk factor and musculoskeletal complaints. Ergonomic risk factors can cause pressure or compression on tendons, nerves, bones and body organs.

Workers who work with awkward posture coupled with repeated movements and exertion of energy for long time can lead to excessive contraction in the muscles and created pressure in the blood vessels and nerves. This condition caused the flow of oxygen and food to muscles become obstructed. In the long time, this condition causes muscle damage and end with paralysis (Dodi et al., 2018).

Ergonomic risk factors in the form of static body postures cause blockages in blood flow leading to the run short of oxygen and glucose supply in the claret. Lactic acid as the resulting body metabolism cannot flow through the blood so it can cause pain in the limbs (Ulfah, Harwanti and Nurcahyo, 2014). Pratama (2017) said unnatural working postures cause the muscles to operate unnaturally which make them exert more energy to perform an activity. This condition leads to fatigue and strains on the muscles and tendons. An unnatural work posture is a working 
posture that moves away from the natural position due to job characteristics, task requirements, work equipment and work stations that are not suitable with the characteristics of the workers (Kurnianto, 2017). Unchecked ergonomic risk factors may lead to faster fatigue build up, decreased concentration, sluggishness, decreased production quality and quantity and decreased productivity (Jalajuwita and Paskarini, 2015).

To prevent musculoskeletal complaints reported by the workers from becoming more severe, the workers are advised to perform stretching exercise designed specifically for the work field. The stretching focuses on the neck, arm, hand, back and legs. According to Harwanti, Ulfah and Aji (2017) working stretching exercise is the most effective to prevent musculoskeletal complaints with 29 movements performed in succession with a hold time of eight seconds. The working stretching exercise movements are performed 3 times per repetition with a length of time per set of 6 to 7 minutes. Owners of batik Madura home industry enterprises are advised to do a redesign to worker stations starting by providing dingklik (a stool with back support and armrests) and rentangan (a wooden/ bamboo frame over which the fabric to be waxed is draped). Local public health centers and health office are advised to provide occupational health programs in all home industries in their working areas with activities such as health checks, health education and counseling.

\section{CONCLUSION}

This study concludes that most of batik workers have age in the preceded adult category. They do not have exercise habit in the unoccupied time and most them have never smoking. The ergonomic risk factors are mostly in the high category. Musculoskeletal complaints that are most felt by the workers are in the high category. The most musculoskeletal complaints felt by batik workers at very painful complaint are mostly in the back organ. The factor with the greatest impact on musculoskeletal complaints in batik workers of Batik Madura home industry is ergonomic risk factors.

\section{ACKNOWLEDGEMENTS}

We would like to declare our gratefulness to the owner of Zulpah Batik Madura home industry who has given their permission for us to carry out this study. We would also like to extend our gratitude to all batik artisans of Zulpah Batik Madura home industry who have participated in the entire research activities.

\section{RENCES}

Arifin, A. N. (2020) Analisis Sikap Kerja Terhadap Musculoskeletal Disorder pada Pembatik Suka Maju Giri Loyo Yogyakarta. Postgraduate Thesis. Semarang: Faculty of Postgraduate Public Health Universitas Negeri Semarang.

Arifin, A. N., Kuswardinah, A. and Deliana, S. M. (2020) 'Analysis of Postures Towards Musculoskeletal Disorders Experienced By Batik Artisans of Sukamaju Giriloyo Yogyakarta', Public Health Perspectives Journal, 5(63), pp. $1-8$.

Briggs, A. M. et al. (2018) 'Reducing The Global Burden of Musculoskeletal Condition', Bulletin of The World Health Organization, 95(5), pp. 366-368.

Statistics Indonesia (2016) Jumlah Tenaga Kerja Industri Mikro dan Kecil Menurut Provinsi, 2013-2015, Industri Mikro dan Kecil. Jakarta: Statistic Indonesia.

Cindyastira, D., Russeng, S. S. and Wahyuni, A. (2014) 'Intensitas Getaran dengan Keluhan Muskuloskeletal Disorders (MSDs)', Jurnal Media Kesehatan Masyarakat Indonesia, 10(4) pp. 234-240.

Dodi, M. et al. (2018) 'Risiko Postur Janggal dengan Kejadian Gangguan Otot Rangka Akibat Kerja (Gotrak) pada Terapis Pijat', Jurnal Kesehatan Komunitas, 4(3), pp. 81-87.

Evadarianto, N. and Dwiyanti, E. (2017) 'Postur Kerja dengan Keluhan Musculoskeletal Disorders pada Pekerja Manual Handling Bagian Rolling Mill', The Indonesian Journal of Occupational Safety and Health, 6(1), pp. 97-106.

Gatchel, R. J. (2014) Handbook of Musculoskeletal Pain and Disability Disorders in the Workplace, Handbook of Musculoskeletal Pain and Disability Disorders in the Workplace. Edited by I. Z. Schultz. New York: Springer Science + Business Media New York.

Graveling, R. A. (2019) Ergonomics and Musculoskeletal Disorders (MSDs) in the Workplace A Forensic and Epidemiological Analysis. First Edit. New York: CRC Press.

Hardianto, Trisnawati, E. and Rossa, I. (2015) 'Faktor-Faktor yang Berhubungan dengan 
Keluhan Musculoskeletal Disorders (MSDs) pada Karyawan Bank X', JUMANTIK: Jurnal Mahasiswa dan Penelitian Kesehatan, 2(2), pp. $1-20$.

Harwanti, S., Ulfah, N. and Aji, B. (2017) 'Pengaruh Workplace Stretching Exercise terhadap Penurunan Keluhan Musculoskeletal Disorders (MSDs) pada Pekerja Batik Tulis di Kecamatan Sokaraja', Jurnal Kesmas Indonesia, 9(1), pp. 49-59.

Hasanah, M. and Winarko (2019) 'Pengaruh Postur Kerja Terhadap Keluhan Muskuloskeletal', Gema Lingkungan Kesehatan, 17(1), pp. 14-19.

Health Research and Development Agency (2013) Riset Kesehatan Dasar (RISKESDAS 2013). Jakarta: Ministry of Health.

International Labour Organization (2018) Meningkatkan Keselamatan dan Kesehatan Pekerja Muda. Jakarta: International Labour Organization.

Isnaini, R. N., Bagyono, T. and Hendrarini, L. (2019) 'Gambaran Faktor Risiko Keluhan Musculoskeletal Disorders pada Pembatik Perempuan di Desa Jarum Kecamatan Bayat Kabupaten Klaten Tahun 2019', in FLEPS 2019 - IEEE International Conference on Flexible and Printable Sensors and Systems, Proceedings, pp. $1-46$.

Jalajuwita, R. N. and Paskarini, I. (2015) 'Hubungan Posisi Kerja dengan Keluhan Muskuloskeletal pada Unit Pengelasan PT. X Bekasi', The Indonesian Journal of Occupational Safety and Health, 4(1), pp. 33-42.

Keyserling, W. M. (2015) 'Workplace Risk Factor and Occupational Musculoskeletal Disorders, Part 1 : A Review of Biomechanical and Psychophysical Research on Risk Factors Associated with Low-Back Pain', American Industrial Hygiene Association, 61(1), pp. 39-50.

Kurnianto, R. Y. (2017) 'Gambaran Postur Kerja dan Risiko Terjadinya Muskuloskeletal pada Pekerja Bagian Welding di Area Workshop Bay 4.2 PT. Alstom Power Energy Systems Indonesia', The Indonesian Journal of Occupational Safety and Health, 6(2), pp. 245-256.

Lindawati and Mulyono (2018) 'Evaluasi Postur Kerja Pengrajin Batik Tulis Aleyya Batik di Yogyakarta', JPH RECODE, 1(2), pp. 131-143.

Marfuah, H. H. (2018) 'Perbaikan Sistem Kerja yang Ergonomis Untuk Mengurangi Kelelahan dan Keluhan Muskuloskeletal dengan Pendekatan
Ergonomi Partisipatori', Dinamika Teknik, 11(1), pp. 1-8.

Mulyati, S. (2019) 'The Relationship Between Work Posture And Musculoskeletal Disorders (Msds) In Laundry Workers In The Area Of Puskesmas Sukamerindu Bengkulu', Proceedings of the 1st International Conference on Inter-professional Health Collaboration., 14, pp. 171-174.

Oesman, T. I., Yusuf, M. and Irawan, L. (2012) 'Analisis Sikap dan Posisi Kerja pada Perajin Batik Tulis di Rumah Batik Nakula Sadewa Sleman', in Seminar Nasional Ergonomi 2012. Yogyakarta: Institut Sains \& Teknologi AKPRIND., pp. 98-103.

Permatasari, F. L. and Widajati, N. (2018) 'Hubungan Sikap Kerja Terhadap Keluhan Musculoskeletal pada Pekerja Home Industry di Surabaya', The Indonesian Journal of Occupational Safety and Health, 7(2), pp. 220-239.

Pratama, D. N. (2017) 'Identifikasi Risiko Musculoskeletal Disorders (MSDs) pada Pekerja Pandai Besi', The Indonesian Journal of Occupational Safety and Health, 6(1), pp. 78-87.

Ramadhiani, K. F., Widjasena, B. and Jayanti, S. (2017) 'Hubungan Durasi Kerja, Frekuensi Repetisi dan Sudut Bahu dengan Keluhan Nyeri Bahu pada Pkerja Batik Bagian Canting di Kampoeng Batik Laweyan Surakarta', Jurnal Kesehatan Masyarakat (e-Journal), 5(5), pp. 215-225.

Rosifah, A., Susmartini, S. and Iftadi, I. (2017) 'Usulan Perbaikan Postur Kerja Operator Proses Produksi Batik Cap di Batik Putri Mulyo dengan Metode Visual Management', PERFORMA : Media Ilmiah Teknik Industri, 16(2), pp. 93-97.

Saputro, C. B., Mulyono and Puspikawati, S. I. (2018) 'Hubungan Karakteristik Individu dan Sikap Kerja terhadap Keluhan Muskuloskeletal pada Pengrajin Batik Tulis', JPH RECODE, 2(1), pp. 1-10.

Sari, R. O. and Rifai, M. (2019) 'Hubungan Postur Kerja dan Masa Kerja dengan Keluhan Musculoskeletal Disorders (MSDs) pada Pembatik Giriloyo', Journal of Chemical Information and Modeling, 53(9), pp. 1689-1699.

Sekaaram, V. and Ani, L. S. (2017) 'Prevalensi Musculoskeletal Disorders (MSDs) pada Pengemudi Angkutan Umum di Terminal Mengwi, Kabupaten Badung-Bali', Intisari Sains Medis, 8(2), pp. 118-124. 
Subramaniam, S. and Murugesan, S. (2015) 'Investigation of Work-Related Musculoskeletal Disorders Among Male Kitchen Workers in South India', International Journal of Occupational Safety and Ergonomics, 21(4), pp. 524-531.

Sumardiyono and Ada, Y. R. (2014) 'Perbedaan Gangguan Muskuloskeletal Pembatik Wanita dengan Dingklik dan Kursi Kerja Ergonomis', Jurnal Kesehatan Masyarakat, 9(2), pp. 144149.

Sumardiyono and Wijayanti, R. (2018) 'Dampak Posisi Duduk Pembatik Tulis Terhadap Risiko Kesehatan dan Pengendaliannya', Jurnal Bakti Masyarakat Indonesia, 1(2), pp. 159-166.
Tarwaka (2019) Ergonomi Industri: Dasar-Dasar Pengetahuan Ergonomi dan Aplikasi di Tempat Kerja. II. Surakarta: Harapan Press Solo.

Ulfah, N., Harwanti, S. and Nurcahyo, P. J. (2014) 'Sikap Kerja dan Risiko Musculoskeletal Disorders pada Pekerja Laundry', Kesmas: National Public Health Journal, 8(7), pp. 313-318.

World Health Organization (2019) Musculoskeletal Conditions. Geneva: World Health Organization 